\title{
GF-120 effects on fruit fly species (Diptera: Tephritidae) in Sahelian agroforestry-based horticultural cropping systems
}

Ousmane ZAKARI-MOUSSA ${ }^{1}$, Alain RATNADASS ${ }^{2,3 *}$, Jean-François VAYSSIÈRES ${ }^{2,4}$, Albert NIKIEMA ${ }^{3,5}$, Dougbedji FATONDJI ${ }^{3}$, Halarou SALHA ${ }^{3}$, Kadri AbOUBACAR ${ }^{1}$, Philippe RYCKEWAERT ${ }^{2}$, Dov PASTERnAK ${ }^{3,6}$

${ }^{1}$ Abdou Moumouni Univ., Fac. Agron., BP 10960, Niamey, Niger

2 CIRAD-Persyst, UPR HortSys, TA B-103 / PS4, Montpellier, F-34398 France, ratnadass@cirad.fr

3 ICRISAT, BP 12404, Niamey, Niger

${ }^{4}$ IITA, Biol. Control Unit Afr., 08 BP 0932 Tri Post., Cotonou, Bénin

${ }^{5}$ Present address: FAO,

For. Dep., Viale delle Terme di Caracalla, 00153 Rome, Italy

6 Present address: 16/12 Harav Goren St., Rishon Letzion, Israel

* Correspondence and reprints

Received 16 January 2012 Accepted 16 March 2012

Fruits, 2012, vol. 67, p. 333-339 (C) 2012 Cirad/EDP Sciences All rights reserved DOI: 10.1051/fruits/2012025 www.fruits-journal.org

RESUMEN ESPAÑOL, p. 339
GF-120 effects on fruit fly species (Diptera: Tephritidae) in Sahelian agroforestry-based horticultural cropping systems.

Abstract - Introduction. In the water-saving and income-generating agroforestry cropping systems developed and promoted by the ICRISAT in the Sudano-Sahelian zone of West Africa, particularly in Niger, fruits of domesticated Ziziphus mauritiana ("apples of the Sahel") are severely damaged by fruit flies (Carpomya incompleta), and chemical pesticide application poses economic, environmental and human health problems. In the Bio-reclamation of Degraded Lands (BDL) system, apple of the Sahel is the main high-value crop, while in the Dryland Eco-Farm (DEF), it is grown alongside watermelon. Sclerocarya birrea (marula plum) is presently being investigated as a dryland tree species for fruit and oil production, either in orchards or such systems as BDL. Materials and methods. To complete preliminary results of earlier studies published elsewhere, we collected and incubated in 2010 ripe fruits of marula plum and watermelon in Sadoré, Niger, where the above-mentioned agroforestry systems are developed, and we recorded emerging fruit flies. We also conducted a spot-spraying experiment (using GF-120) in an apple of the Sahel orchard in Niamey in 2010; we recorded undamaged and damaged fruits and incubated the latter. In the same orchard, we set up in 2011 a fruit fly trapping survey targeting the invasive species Bactrocera invadens (Chempac ${ }^{\circledR}$ traps using methyl eugenol as the attractant). Results and discussion. The results showed that only Ceratitis cosyra emerged from marula plums, and only Dacus spp. from watermelon. The GF-120 spot-spraying experiment showed that C. incompleta was not attracted / intoxicated, contrary to Ceratitis spp. and Dacus spp.; the sprayed trees yielded significantly more marketable fruits than unsprayed ones; only $C$. incompleta emerged from damaged fruit. Detection trapping revealed for the first time the presence of B. invadens in the Sahelian zone of Niger, including at the time of apple of the Sahel fruit production. Conclusion. This, alongside results of earlier studies, suggests a repellent effect of GF-120 on the monophagous C. incompleta species (Trypetinae), while it is attractive to oligophagous/polyphagous Dacinae fruit flies; some of them (e.g., Dacus spp.) damage watermelon, which is part of the DEF system, and produce fruit at the flies; some of them (e.g., Dacus spp.) damage watermelon, which is part of the DEF system, and produce fruit at the
same time as the jujube tree. The prospects for harnessing these two opposite regulation pathways are discussed.

Niger / Ziziphus mauritiana / Citrullus lanatus / pest control / Carpomya incompleta / Bactrocera invadens / Ceratitis / Dacus / control methods / integrated control / attractants / repellents

Impacts du GF-120 sur des mouches des fruits (Diptera : Tephritidae) en systèmes agroforestiers sahéliens à base de cultures horticoles.

Résumé - Introduction. Dans les systèmes de culture agroforestiers économes en eau et générateurs de revenus promus par l'ICRISAT dans la zone soudano-sahélienne d'Afrique de l'Ouest, en particulier au Niger, les fruits du jujubier domestiqué Ziziphus mauritiana (" pommes du Sahel ") sont sévèrement attaqués par des mouches des fruits (Carpomya incompleta); l'application de pesticides de synthèse pose des problèmes de rentabilité économique, d'ordre environnemental et de santé publique. Dans le système de Bio-récupération des terres dégradées (BDL), la pomme du Sahel est la principale culture à forte valeur, tandis que dans l'Eco-ferme sahélienne (DEF), elle est cultivée avec la pastèque. Par ailleurs, dans la zone semi-aride, le prunier africain Sclerocarya birrea est en cours d'évaluation en vergers ou dans des systèmes comme le BDL pour sa production en fruits et en huile. Matériel et méthodes. En complément d'études antérieures publiées par ailleurs, nous avons collecté et mis en incubation en 2010 des prunes africaines et des pastèques à Sadoré (Niger) où les systèmes agroforestiers sus-mentionnés sont développés ; les mouches des fruits qui en ont émergé ont été observées. En 2010, nous avons aussi conduit un essai de traitement insecticide par taches avec du GF-120 dans un verger de jujubiers à Niamey; nous avons comptabilisé les fruits indemnes et ceux qui étaient attaqués ; les fruits attaqués ont été mis en incubation. Dans le même verger, nous avons mis en place en 2011 un essai de piégeage des mouches des fruits visant l'espèce invasive Bactrocera invadens (pièges Chempac ${ }^{\circledR}$ contenant du méthyl-eugénol comme attractif). Résultats et discussion. Les résultats ont montré que seule l'espèce Ceratitis cosyra émergeait des prunes africaines, et que seules des espèces de Dacus spp. émergeaient des pastèques. L'essai de traitement en taches au GF-120 a montré que la mouche C. incompleta n'était pas attirée / intoxiquée, contrairement à Ceratitis spp. et Dacus spp. ; que les arbres traités avaient un rendement en fruits commercialisables significativement plus élevé que celui des arbres non traités; que seule l'espèce $C$. incompleta émergeait des fruits attaqués. Le piégeage de détection a révélé pour la première fois la présence de $B$. invadens dans la zone sahélienne du Niger, y compris en période de production de pommes du Sahel. Conclusion. Nos résultats, ajoutés à ceux d'études antérieures, suggèrent que le GF-120 a un effet répulsif sur l'espèce monophage $C$. incompleta (Trypetinae), mais attractif sur les mouches oligophages/polyphages Dacinae ; certaines d'entre elles, dont Dacus spp., s'attaquent à la pastèque qui fait partie du système de culture DEF et fructifie à la même période que le jujubier. Les perspectives d'exploitation de ces deux voies de régulation opposées sont discutées.

Niger / Ziziphus mauritiana / Citrullus lanatus / lutte antiravageur / Carpomya incompleta / Bactrocera invadens / Ceratitis / Dacus / méthode de lutte / lutte intégrée / attractif / répulsif 


\section{Introduction}

The Sudano-Sahelian zone of West Africa is characterized by recurrent dry spells, land degradation and low staple crop yields, resulting in increased poverty. In this zone, the International Crops Research Institute for the Semi-Arid Tropics (ICRISAT) and its partners are promoting water-saving and income-generating systems mixing food crops and vegetables with fruit trees, particularly in the water harvesting-based Bioreclamation of Degraded Lands (BDL) and Dryland Eco-Farm (DEF) systems [1, 2].

In these systems, several perennial crops may assume key roles as high-value crops, both for nutritional and economic value. This is notably the case of domesticated Ziziphus mauritiana Lam. (Rhamnaceae), the Indian jujube locally called "Sahel apple", which is the most popular perennial high-value crop in both BDL and DEF systems. Marula plum (Sclerocarya birrea [A. Rich.] Hoscht.) is under investigation as a potential candidate fruit tree for dryland plantations or BDL, while in the Dryland

Figure 1.

Marula plum tree (Sclerocarya birrea) in Sadoré (Niger).

\section{Figure 2.}

Fruit fly-damaged marula fruits in Sadoré (Niger).

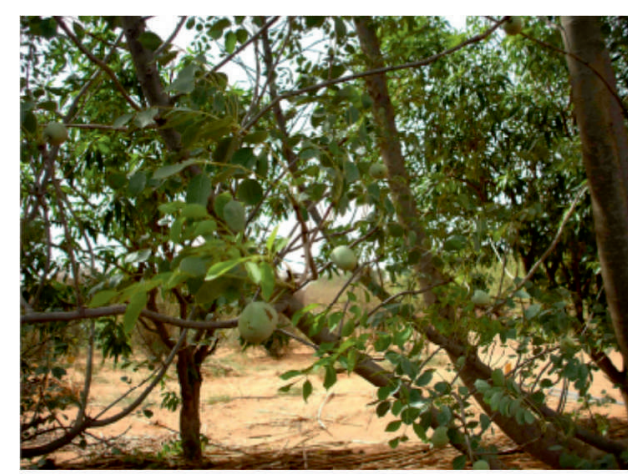

Eco-Farm (DEF), grafted jujube trees grow alongside watermelon Citrullus lanatus (Thumb) Matsun and Nakai [3].

Sahel apple fruit is a soft, juicy drupe of $2 \mathrm{~cm}$ diameter, though with improved cultivars the fruit size could be $6.2-\mathrm{cm}$ long and $4.5-\mathrm{cm}$ wide. This species is also studied in the station of Katchari (north of Burkina Faso) using different improved cultivars [4].

Ziziphus mauritiana fruit suffer high infestation by the fruit fly Carpomya incompleta Becker, 1903, making pest control mandatory and therefore production risky, both economically and environmentally, if chemical insecticides are sprayed.

Studies conducted in 2009 in a Sahel apple orchard in Sadore, the ICRISAT research station in Niger, using the spot treatment technique [5], suggested a repellent effect of the spinosad bait spray GF-120 (Success Appat ${ }^{\circledR}$ Dow AgroSciences) on C. incompleta [6], resulting in the protection of sprayed jujube trees. To further document the potential for managing the Sahel apple fruit fly in an environmentally-friendly manner, based on the "push-pull" (stimulodeterrent diversionary) principles [7], we report here complementary observations that were made on marula plum and watermelon in Sadoré in 2010, and further experiments conducted in a jujube orchard at the Abdou Moumouni University of Niamey in 2010 and 2011.

\section{Materials and methods}

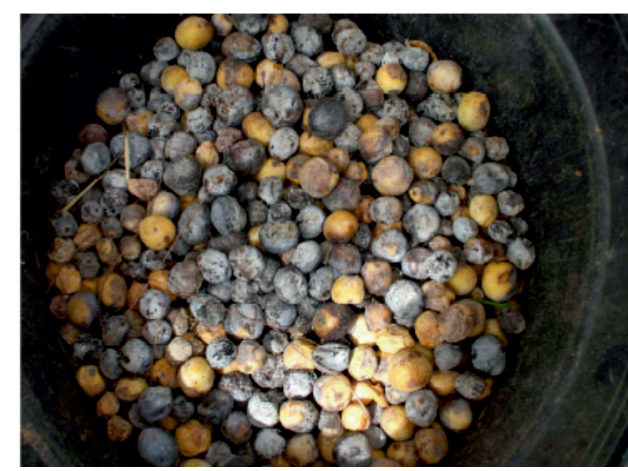

\subsection{Fruit fly observations on marula plum and watermelon}

In June 2010, observations were made on ripe and fallen fruits of marula plum in Sadoré (figures 1, 2), and, in October 2010, on ripening watermelons at the time of the Sahel apple fruiting in the DEF system (figure 3). Damaged fruits were incubated in the laboratory in containers whose bottoms were filled with sand, and fruit fly adults were identified after emergence. 


\subsection{Jujube tree spot-spraying experiment}

In September 2010, six trees of Z. mauritania $\mathrm{cv}$. Umran were selected at random in a Sahel apple orchard at the Faculty of Agronomy, University of Niamey $\left(13^{\circ} 30^{\prime} \mathrm{N}\right.$, $2^{\circ} 09^{\prime} \mathrm{E}$ ); four trees were sprayed with a GF120 solution once a week for 3 weeks and two trees remained unsprayed. Inter-tree spacing was $6 \mathrm{~m} \times 7 \mathrm{~m}$.

The bait spray was applied with a HD400 (Micron ${ }^{\circledR}$ sprayers LTDA, Bromyard, UK) manual sprayer using a conventional conical nozzle calibrated to deliver droplets of 2-6 mm from a spray mixture of $1.0 \mathrm{~L}$ of water and $0.1 \mathrm{~L}$ of GF-120. In this orchard, no other chemical treatment of any kind was applied before or during the experiment. The dosage of 0.1 L of GF-120 per four trees, namely per $168 \mathrm{~m}^{2}$, would thus correspond to the recommended dosage of $1.5 \mathrm{~L} \cdot \mathrm{ha}^{-1}$, if one tree out of four was sprayed.

White linen sheets were placed under the trees after spraying and fallen flies following the treatments were observed and collected. Observations took place over a period of $6 \mathrm{~h}$ following the treatment.

Ripe fruits were then harvested every week for 3 weeks from mid-November to early December and harvested fruits were weighed; a distinction was made between marketable and unmarketable ones, the latter being basically those showing fruit fly damage (figure 4). Marketable fruit weight data were analyzed using the parametric test module (Student $t$ test) of XLSTAT ${ }^{1}$.

Damaged fruits were incubated in the laboratory in containers whose bottoms were filled with sand, and fruit fly adults were identified after emergence, based on taxonomic keys [8].

\subsection{Bactrocera invadens detection trapping}

In addition to these previous experiments, we monitored Bactrocera invadens Drew

${ }^{1}$ XLSTAT version 2009.6.02, Addinsoft (Ed.), 2009, http://www.xlstat.com.

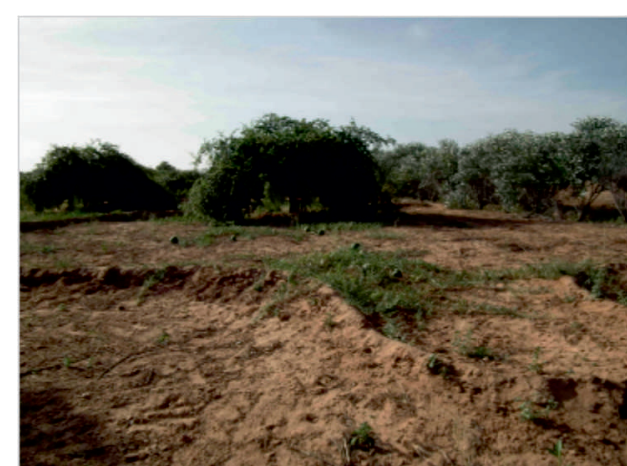

Figure 3.

Watermelon (Citrullus lanatus) Jujube tree (Ziziphus mauritiana) association in the Dryland Eco-Farm (DEF) system in Sadoré (Niger).

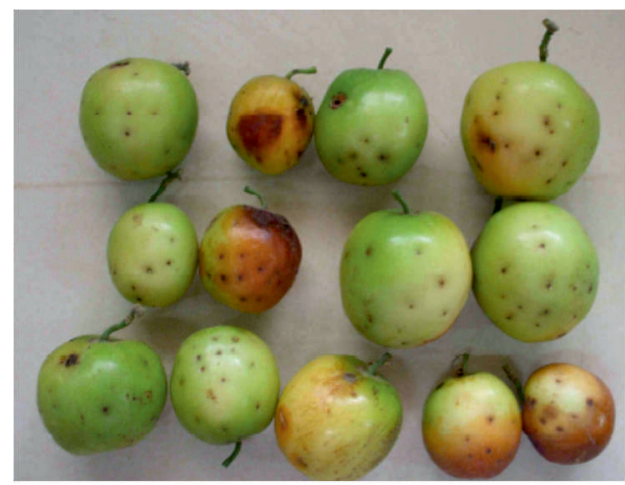

Figure 4.

Jujube fruits (apples of the Sahel) damaged by fruit flies (Niamey, Niger).

Tsuruta \& White male fly populations for 4 months in 2011, in the University of Niamey jujube orchard, using parapheromone (methyl eugenol) lure-baited Chempac ${ }^{\circledR}$ Bucket traps [9, 10]. Two traps were placed at about $1.5 \mathrm{~m}$ above ground in the shade of two $Z$. mauritiana trees (cv. Umran and a local wild cultivar) $160 \mathrm{~m}$ apart. Traps were set up at the end of the second week of each month from July 2011 to October 2011, and inspected one week later, then removed and set up again (with fresh lures) the second week of the following month. All trapped B. invadens male flies were recorded.

\section{Results}

Tephritid fruit flies attracted by GF-120 as spot sprays in the jujube orchard in Niamey belonged to the Ceratitis and Dacus genera. Ceratitis silvestrii Bezzi was the dominant Ceratitis species, but $C$. cosyra (Walker) was also present. Dacus species included both $D$. ciliatus Loew and D. vertebratus Bezzi. 
Table I.

Fruit fly species emerged during fruit collections in Sadoré and Niamey (Niger) in 2010.

\begin{tabular}{lcccccc} 
Sampling location & Fruit sampled & Observation date & Carpomya sp. & Ceratitis spp. & Dacus spp. & Bactrocera spp. \\
\hline Sadoré & Marula plum & June & 0 & + & 0 & 0 \\
& Watermelon & October & 0 & 0 & + & 0 \\
Niamey & Jujube & November & + & 0 & 0 & 0 \\
\hline 0: not recorded; + : emerged. & & & &
\end{tabular}

Figure 5.

Bactrocera invadens monthly catches in a jujube orchard (Niamey, Niger, 2011).

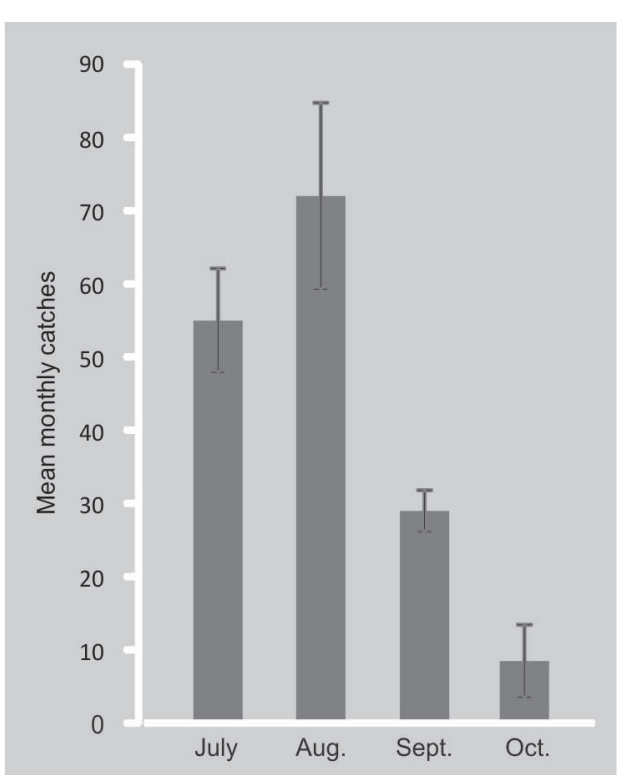

Carpomya incompleta was the only fruit fly species to be incubated from damaged jujube fruits (table I). On the other hand, several adult Dacus fruit flies (mainly D. vertebratus) emerged from the watermelons collected in October 2010 in Sadoré, while, at this same location, Ceratitis cosyra was found to heavily infest marula plum fruits (table I), with infestation of up to (18.2 \pm 5.28) larvae per fruit in June 2010 .

The results on marketable Sahel apple fruit weights recorded in Niamey in 2010 on GF-120-sprayed trees compared with unsprayed controls showed a significant positive effect of GF-120 spraying on the production of marketable fruits $[(2.0 \pm 0.7) \mathrm{kg} v s .0 .0 \mathrm{~kg}]$.

The results from parapheromone trapping at the University of Niamey in 2011 showed high populations of B. invadens, particularly in July and August before the watermelon and jujube fruiting period, but it appears that the pest is still present in September and October, at the time of fruit production (figure 5).

\section{Discussion}

It was thus found that the repellent effect of GF-120 on C. incompleta, reported in Sadoré in 2009 [6], was probably at play in 2010 in Niamey, as suggested by the observation on marketable fruit production on GF-120-sprayed trees compared with unsprayed ones.

Actually, Carpomya incompleta, which is specific (monophagous) to Ziziphus spp., seems to be strongly repelled by GF-120 spraying, while Ceratitis spp., which is more polyphagous, is attracted and killed by the same at the same dosage (alongside, although to a lesser extent, the oligophagous Dacus spp. known as pests of cucurbit crops).

In another test in Sadoré, GF-120 as a spot treatment on Sodom's apple shrub [Calotropis procera (Ait.) Ait. F., Asclepiadiaceae] did not attract the fruit fly specific to this plant, Dacus longistylus Wiedemann, 1830, although present in large numbers in the environment (namely, on the sprayed plants as well as on neighboring Calotropis shrubs) (unpubl. data).

Actually, in the absence of GF-120 spraying, fruit flies of several species were observed resting on flowering jujube trees 
both in Sadoré and Niamey (figure O), so it is not known whether Ceratitis spp. and other Dacini species intoxicated in 2009 had been attracted over a large distance or not. On the other hand, other results showed that, when sprayed on border crops, GF-120 was an attractant to cucurbit Dacini fruit flies in Hawaii [11] and Benin [12] with, in the latter location, a significant effect on Dacus spp. (particularly D. vertebratus) infesting watermelon. In our studies, Carpomya incompleta was the only fruit fly species to be incubated from damaged fruits in both Sadore and the University of Niamey, confirming earlier observations [13].

Our results thus suggest that GF-120 could be used as a repellent to protect jujube trees from the fruit fly C. incompleta. Watermelon being part of the DEF system [2, 3], and Dacus fruit flies emerging from cucurbits, including watermelons, being attracted to and intoxicated by GF-120, one could kill two birds (or fly species) with one stone (or spray) in this system, using two opposite pathways, since both Sahel apple and watermelon flower and fruit at the same time. The same applies to Bactrocera cucurbitae (Coquillett), well established in Niger, which was recorded on watermelon in Côte d'Ivoire, Guinea, Mali and Senegal [14]. In an earlier experiment, this species was found to be attracted by GF-120 sprayed on jujube trees [6]. However, this still needs to be tested experimentally, in actual DEF systems, with lower dosages on the one hand, and with untreated systems as adequate controls on the other hand, with several replications, and damage measurement on both jujube and watermelon.

In case its effectiveness is confirmed, such a system might become even more relevant with the threat to the Sahel apple by the invasive species $B$. invadens since Tankouano et al. found that this species was involved in damage to Sahel apples in Burkina Faso [15], and that, in Benin, B. invadens emerged from drupes of Z. mauritiana collected near the border with Burkina Faso, with 70 adults per kg of fruits [16]. In Niger, fruit fly species associated with jujube fruits should thus be further investigated; indeed, an already high prevalence of $B$. invadens in Niamey, including

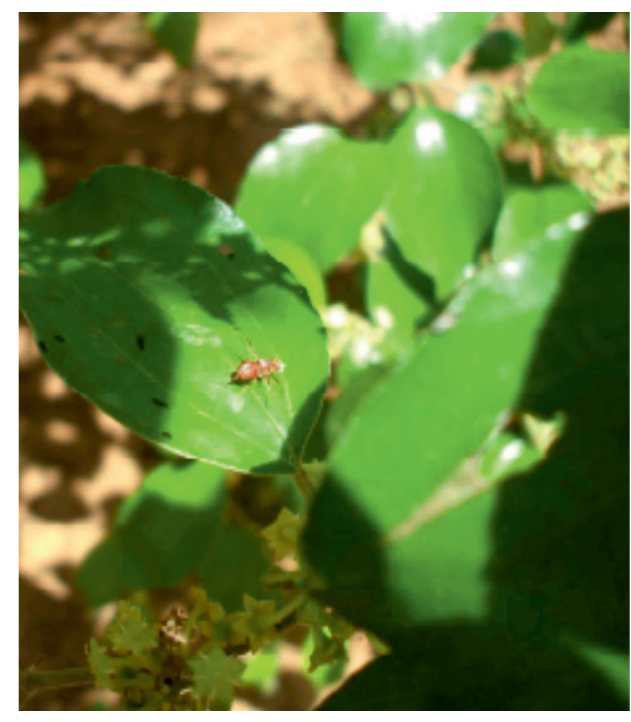

Figure 6.

Dacini fruit fly on a flowering jujube tree (Niamey, Niger).

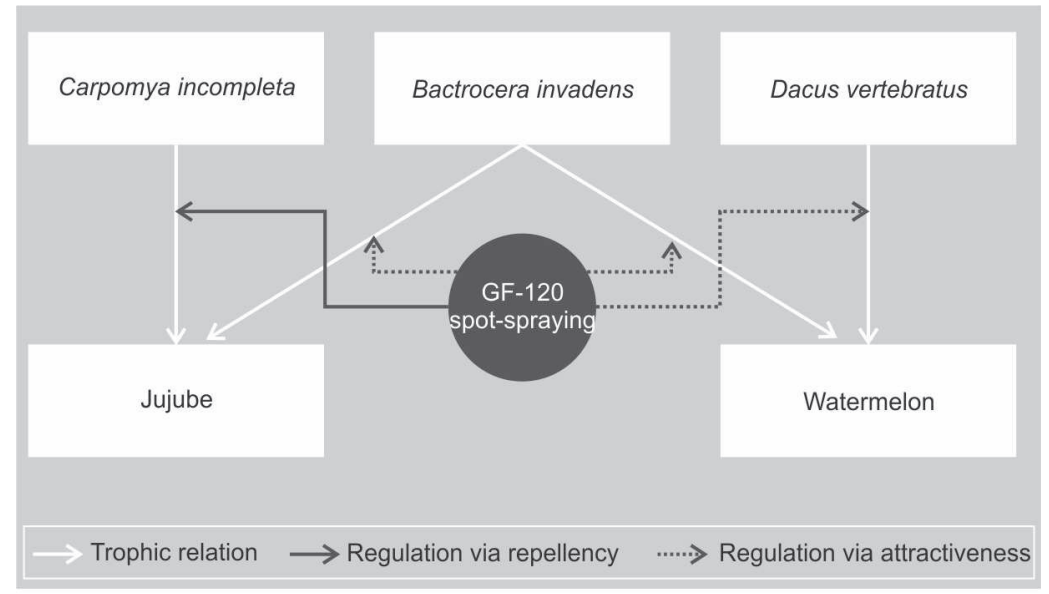

during the Ziziphus flowering period, was evidenced by our methyl eugenol trapping, the year that followed the spot-spraying experiment. Based on results obtained on this species on mango [5], the spot-spraying technique is likely to work on the Sahel apple as well, and on watermelon since this crop was reported as a host for $B$. invadens from Benin [16], although at low levels, while the infestation rate was higher in Tanzania [17].

However, our proposed "win-win" strategy (figure 7), if confirmed, can only be applied to fruit or vegetable species flowering at the same time as the Sahel apple, namely not, for instance, to the highly fruit fly-susceptible marula plum.
Figure 7.

Representation of a "win-win" strategy to "kill three fly species with one spray" in a Dryland Eco-Farm (DEF) system. 


\section{Acknowledgements}

The University of Niamey's and CIRAD's core budgets funded these studies. GF-120 (Success Appat ${ }^{\circledR}$ ) used in the spot treatment experiment was provided by Dow AgroSciences, France (Mr Michel Villeneuve) via Sadjera S.A., Niger (Mr Ganda Moussa). Methyl eugenol and Chempac ${ }^{\circledR}$ bucket traps were provided by Citrus Research International, South Africa (Mrs De Villiers).

\section{References}

[1] Pasternak D., Senbeto D., Kumar S., Fatondji D., Woltering L., Ratnadass A., Ndjeunga J., Bioreclamation of degraded African lands with women empowerment, Chronica Hortic. 49 (2009) 24-26.

[2] Fatondji D., Pasternak D., Nikiema A., Senbeto D., Woltering L., Ndjeunga J. Abdoussalam S., The Dryland Eco-Farm: A potential solution to the main constraints of rain-fed agriculture in the semi-arid tropics of Africa: Exploring the scientific facts, in: Bationo A., Waswa B., Okeyo J.M., Maina F., Kihara J. (Eds.), Innovations as Key to the Green Revolution in Africa, Springer Sci. + Bus. Media B.V., Dordrecht, Neth., 2011, pp. 1115-1123.

[3] Fatondji D., Pasternak D., Woltering L., Watermelon production on stored rainwater in Sahelian sandy soils, Afr. J. Plant Sci. 2 (2008) 151-160.

[4] Ganaba S., Kiéni B., Barry H., Coulibaly B., Introduction de cultivars de jujubiers (Ziziphus mauritiana Lam.) en zone sahélienne du Burkina Faso, Fruits 62 (2007) 247254.

[5] Vayssières J.-F., Sinzogan A., Korie S., Ouagoussounon I., Thomas-Odjo A., Effectiveness of spinosad bait sprays (GF-120) in controlling mango-infesting fruit flies (Diptera: Tephritidae) in Benin, J. Econ. Entomol. 102 (2009) 515-521.

[6] Ratnadass A., Ryckewaert P., Claude Z., Nikiema A., Pasternak D., Woltering L., Thunes K., zakari-Moussa O., New ecological options for the management of horticultural crop pests in Sudano-sahelian agroecosystems of West Africa, Acta Hortic. 917 (2011) 85-91.
[7] Cook S.M., Khan Z.R., Pickett J.A., The use of push-pull strategies in integrated pest management, Annu. Rev. Entomol. 52 (2007) 375-400.

[8] White I.M., Elson-Harris M.M., Fruit flies of economic importance: their identification and bionomics, Int. Inst. Entomol., Lond., U.K., 1992.

[9] Tan K.H., Tokushima I., Ono H., Nishida R., Comparison of phenylpropanoid volatiles in male rectal pheromone gland after methyl eugenol consumption, and molecular phylogenetic relationship of four global pest fruit fly species: Bactrocera invadens, $B$. dorsalis, B. correcta and B. zonata, Chemoecology 21 (2011) 25-33.

[10] Manrakhan A., Hattingh V., Venter J-H., Holtzhausen M., Eradication of Bactrocera invadens (Diptera: Tephritidae) in Limpopo Province, South Africa, Afr. Entomol. 19 (2011) 650-659.

[11] Vargas R.I., Pinero J.C., Jacome I., Revis H.C., Prokopy R.J., Effectiveness of GF-120 $\mathrm{NF}$ naturalyte fruit fly bait spray against different ages of melon fly (Diptera: Tephritidae) females when applied to border crops of various widths, Proc. Hawaii. Entomol. Soc. 41 (2009) 15-23.

[12] Hanna R., Azandeme G., Gnanvossou D., Identification of roosting hosts and their integration into bait application for the management of cucurbit flies in West Africa, in: Munoz B.S., Lopis V.N., Urbaneja A. (Eds.), Abstr. 8th Int. Symp. Fruit Flies of Economic Importance, Valencia, Spain, 2010, p. 285

[13] Rhousseini S., Inventaire de l'entomofaune nuisible du jujubier dans la station de recherche agricole de I'ICRISAT de Sadoré, Abdou Moumouni Univ., Diss., Niamey, Niger, 2005.

[14] Vayssières J.-F., Rey J.-Y., Traoré L., Distribution and host plants of Bactrocera cucurbitae in West and Central Africa, Fruits 62 (2007) 391-396.

[15] Tankoano M., Diallo B., Ouedraogo S., Some N., Noula K., Kalinganire A., Inventaire des insectes nuisibles aux fruits des variétés indiennes de Ziziphus mauritiana Lam. (Rhamnaceae) au Burkina Faso, Fruits 67 (3) 189-200.

[16] Goergen G., Vayssières J.-F., Gnanvoussou D., Tindo M., Bactrocera invadens (Diptera Tephritidae), a new invasive fruit fly pest for the Afrotropical region: host plant range and 
distribution in West and Central Africa, Environ. Entomol. 40 (2011) 844-854.

[17] Mwatawala M.W., De Meyer M., Makundi R.H., Maerere A.P., Host range and distribu- tion of fruit-infesting pestiferous fruit flies (Diptera, Tephritidae) in selected areas of Central Tanzania, Bull. Entomol. Res. 99 (2009) 629-641.

\section{Impactos del GF-120 en moscas de la fruta (Diptera: Tephritidae) en sistemas agroforestales sahelianos a base de cultivos hortícolas.}

Resumen - Introducción. En los sistemas de cultivo agroforestales ahorradores de agua y generadores de ingresos promovidos por el ICRISAT (Instituto Internacional de Investigación de Cultivos para las Zonas Tropicales Semiáridas) en la zona sudanosaheliana de África Occidental, en particular en Níger, los frutos del azufaifo cultivado Ziziphus mauritiana ("manzana del Sáhel") están muy atacados por las moscas de la fruta (Carpomya incompleta). La aplicación de plaguicidas sintéticos plantea problemas de rentabilidad económica, de orden medioambiental y de salud pública. En el sistema de biorrecuperación de tierras degradadas (BDL, en sus siglas originales), la manzana del Sáhel es el cultivo principal con un valor fuerte, mientras que en la Eco-granja saheliana (DEF, en sus siglas originales), se cultiva junto a la sandía. Por otro lado, en zona semiárida, se encuentra el ciruelo africano Sclerocarya birrea en curso de evaluación, en vergeles o en sistemas como el BDL para su producción de frutos y de aceites. Material y métodos. Como complemento de anteriores estudios publicados aparte, cosechamos y pusimos en incubación ciruelas africanas y sandías, en 2010, en Sadoré (Níger), donde los sistemas agroforestales mencionados arriba están desarrollados. Las moscas de la fruta emergidas allí fueron observadas. En 2010, llevamos igualmente a cabo un ensayo de tratamiento insecticida por manchas de GF-120 en un vergel de azufaifos en Niamey; contabilizamos los frutos indemnes y aquéllos que habían sido atacados. Los frutos atacados se pusieron en incubación. En el mismo vergel, en 2011, ejecutamos un ensayo de trampeo de las moscas de la fruta, cuyo blanco era la especie invasora Bactrocera invadens (trampas Chempac® conteniendo el atrayente metil eugenol). Resultados y discusión. Los resultados mostraron que únicamente la especie Ceratitis cosyra emergía de las ciruelas africanas, y que únicamente las especies de Dacus spp. emergían de las sandías. En el ensayo de tratamiento por manchas de GF-120 se demostró que la mosca $C$. incompleta no estaba atraída/intoxicada, contrariamente a Ceratitis spp. y a Dacus spp.; que los árboles tratados poseían un rendimiento de frutas comerciables mucho más alto que los árboles no tratados; que únicamente la especie $C$. incompleta emergía de los frutos atacados. Por primera vez, el trampeo de detección mostró la presencia de $B$. invadens en la zona saheliana de Níger, incluso en periodo de producción de manzanas de Sáhel. Conclusión. Nuestros resultados, añadidos a aquéllos recogidos en los estudios anteriores, sugieren que el GF-120 tiene un efecto repulsivo en la especie monófaga $C$. incompleta (Trypetinae), pero atrayente en las moscas oligófagas/polífagas Dacinae; algunas de ellas, entre las cuales Dacus spp., atacan la sandía, que forma parte del sistema de cultivo DEF y fructifica durante el mismo periodo que el azufaifo. Las perspectivas de explotación de ambas vías de regulación opuestas son debatidas.

Níger / Ziziphus mauritiana / Citrullus lanatus / control de plagas / Carpomya incompleta / Bactrocera invadens / Ceratitis / Dacus / métodos de control / lucha integrada / atrayentes / repelentes 